\title{
PEMILIHAN MULTI-KRITERIA PEMASOK DEPARTMENT STORE MENGGUNAKAN METODE FUZZY AHP DAN TOPSIS
}

\author{
Carla Olyvia Doaly ${ }^{1)}$, Parwadi Moengin ${ }^{2)}$, Gebriel Chandiawan ${ }^{1)}$ \\ ${ }^{1)}$ Program Studi Teknik Industri Universitas Tarumanagara \\ ${ }^{2)}$ Program Studi Teknik Industri Trisakti \\ e-mail: carlaol@ft.untar.ac.id; parwadi@ trisakti.ac.id; gebriel.chandiawan@gmail.com
}

\begin{abstract}
ABSTRAK
Department Store merupakan perusahaan yang bergerak dalam bidang fashion. Industri fashion di Indonesia tumbuh sangat pesat, dengan persaingan yang semakin ketat sehingga untuk dapat bertahan, penyediaan produk yang tepat bagi konsumen, di waktu yang tepat dengan harga yang ekonomis menjadi tantangan utama. Pemilihan supplier yang tepat menjadi sangat penting untuk mewujudkan hal tersebut diatas. Banyak kriteria yang bisa menjadi pertimbangan dalam pemilihan supplier, sehingga ini menjadi keputusan yang sulit. Dalam Penelitian ini pemilihan supplier dilakukan dengan menerapkan Multiple Criteria Decision Making (MCDM) menggunakan metode Fuzzy AHP dan TOPSIS. Metode Fuzzy AHP dapat meminimalkan ketidakpastian (uncertainty) yang dapat terjadi dalam pengambilan keputusan. Sedangkan TOPSIS dengan membandingkan jarak solusi ideal negative dan positif. Pemilihan supplier dilakukan dengan mempertimbangkan 5 kriteria, 15 sub kriteria dan 5 alternatif dengan tujuan mendapatkan alternatif terbaik berdasarkan atas 5 kriteria . Hasil perhitungan Fuzzy AHP menunjukkan bahwa merk PRL sebagai peringkat 1 dengan bobot 0,33 dan merk $C$ pada peringkat ke 2 dengan bobot 0,22. Sedangkan pada perhitungan TOPSIS merk PRL sebagai peringkat 1 dengan bobot 0.63, merk $C$ pada peringkat 2 dengan bobot 0.49, disusul dengan merk BK, HP dan yang terakhir TE, dengan bobot masing-masing $0.32,0.30$ dan 0.15
\end{abstract}

Kata kunci: Pemilihan Supplier, MCDM, Fuzzy AHP, TOPSIS.

\begin{abstract}
Department Store is a company engaged in the field of fashion. The fashion industry in Indonesia is growing very rapidly, with increasingly fierce competition so as to be able to survive, providing the right products for consumers, at the right time and economical prices is a major challenge. The selection of the right supplier becomes very important in realizing the above. Many criteria can be considered in the selection of suppliers, so this is a difficult decision. In this research, supplier selection is done by applying Multiple Criteria Decision Making (MCDM) using the Fuzzy AHP and TOPSIS methods. Fuzzy AHP method can minimize the uncertainty that can occur in decision making. Whereas TOPSIS by comparing the distance of the ideal negative and positive solutions. Supplier selection is done by considering 5 criteria, 15 sub criteria and 5 alternatives with the aim of getting the best alternative based on 5 criteria. Fuzzy AHP calculation results show that the PRL brand as rank 1 with a weight of 0.33 and brand $C$ in the rank of 2 with a weight of 0.22 . Whereas in the calculation of TOPSIS $P R L$ brand as rank 1 with a weight of 0.63, brand $C$ at rank 2 with a weight of 0.49 , followed bybrands BK, HP and finally TE, with weights of 0.32,0.30 and 0.15 , respectively.
\end{abstract}

Keywords: Supplier Selection, MCDM, Fuzzy AHP, TOPSIS.

\section{PENDAHULUAN}

Industri fashion tumbuh dengan pesat di seluruh dunia dan hal yang serupa pun terjadi di Indonesia. Gati Wibawaningsih yang merupakan Direktur Jendral Industri Kecil dan Menengah Kementerian Perindustrian mengatakan bahwa tahun 2016 hingga sekarang industri fashion memiliki kontribusi yang cukup baik, dengan nilai tambah produk di bidang industri. Department Store merupakan perusahaan yang bergerak dalam bidang fashion. Persaingan dalam industri fashion saat ini semakin ketat. Salah satu hal yang membuat perusahaan retail fashion bertahan adalah penyediaan produk yang tepat bagi konsumen, di waktu yang tepat, dan harga yang ekonomis. Ketersediaan produk dan harga 
jual yang ekonomis hanya bisa terjadi apabila adanya kolaborasi yang terjalin baik antara perusahaan, supplier, dan distributor. Dalam konteks supply chain, koordinasi antara perusahaan dengan para supplier biasanya merupakan hubungan yang sangat sulit sekaligus penting dalam jaringan distribusi Oleh karena supplier adalah bagian eksternal perusahaan, koordinasi menjadi tidak mudah kecuali kerjasama dan pertukaran informasi antara keduanya telah terintegrasi. Departement Store biasanya memiliki lebih dari satu supplier. Menentukan supplier yang tepat bagi Departemen Store menjadi sangat penting agar memperoleh produk yang berkualitas tinggi. Oleh karena itu untuk menentukan supplier yang tepat, perusahan perlu mengetahui kriteria-kriteria yang dibutuhkan dalam mengidentifikasi dan mengevaluasi supplier yang telah dan yang akan bekerjasama dengan mereka [1]. Permasalahan yang dihadapi dalam pemilihan supplier adalah banyaknya kriteria-kriteria yang bisa menjadi bahan pertimbangan, rumit kadang tidak terstruktur dengan baik.

Dalam penelitian ini pemilihan supplier dilakukan dengan menerapkan Multiple Criteria Decision Making (MCDM) yaitu metode pengambilan keputusan untuk menetapkan alternatif terbaik dari sejumlah alternatif yang ada berdasarkan beberapa kriteria tertentu [2]. Metode MCDM yang digunakan dalam penelitian ini adalah Fuzzy AHP dan TOPSIS (Technique for Order Preference by Similarity to Ideal Solution). Fuzzy AHP menggunakan logika fuzzy yang berperan dalam meminimalisir ketidakpastian dalam pengambilan keputusan salah satunya dengan menggunakan pendekatan triangular fuzzy number. Sedangkan metode TOPSIS mencari solusi alternatif yang mempunyai jarak terdekat dengan solusi ideal positif dan terjauh dari solusi ideal negatif. Pemilihan supplier sebelumnya menggunakan metode AHP [3]. Metode Fuzzy AHP menhasilkan keputusan yang lebih baik dibandingkan dengan AHP, karena dapat meminimalisir ketidakpastian dalam mendeskripsikan keputusan yang samar-samar pada AHP. Metode Fuzzy AHP dan TOPSIS telah banyak digunakan dalam penelitian sebelumnya dalam pengambilan keputusan yaitu pemilihan operating system [4], penggunaan senjata [5], Transhippment site selections [6], Promosi Jabatan [7], pemilihan distro Linux [8], dan penempatan karyawan [9].

Informasi mengenai potensi pemilihan supplier dan cara pemilihan yang cocok bagi perusahaan yang bergerak di bidang fashion berdasarkan penelitian sebelumnya mengidentifikasi bahwa 50 persen perusahaan di bidang industri yang berbeda memiliki cara pengevaluasian supplier yang formal [10]. Ada beberapa kriteria yang paling sering digunakan adalah delivery [11], flexibility [12], cost [13], quality [14] dan reliability [15]. Namun untuk industri fashion ada penambahan dua kriteria lagi, yaitu product variety dan style [14]. Kriteria yang telah disebutkan di atas memiliki indikator masing-masing, yaitu: delivery indikatornya adalah lokasi geografis, ketentuan pengiriman, total order lead time; untuk flexibility indikatornya adalah kapasitas, inventory, availability, information sharing, negotiability, dan customization; cost indikatornya adalah supplier selling cost, internal cost, ordering dan invoice; quality indikatornya adalah continues improvement program, customer service, certification, dan on time shipment; reliability indikatornya adalah feeling of trust, country's political situation, currency exchange, dan situation warranty police; dan untuk product variety indikatornya adalah size, shape, dan structure; sedangkan style indikatornya adalah color dan appearance.

\section{METODE PENELITIAN}

Penelitian dilakukan pada Department Store di wilayah Jakarta Barat. Selanjutnya melakukan studi literature mempelajari hubungan supplier dan buyer, karakteristik pemilihan supplier, metode pengambilan keputusan multikriteria. Dalam penelitian ini 
menerapkan metode multi criteria decision making (MDCM) yaitu Fuzzy AHP dan TOPSIS (Technique for Order Preference by Similarity to Ideal Solution) suatu metode pengambilan keputusan untuk menetapkan alternatif terbaik dari sejumlah alternatif berdasarkan beberapa kriteria yang akan menjadi bahan pertimbangan.

\section{Fuzzy Analytical Hierarchy Process (Fuzzy AHP)}

Fuzzy AHP dikembangkan oleh Chang pada tahun 1996 merupakan pengembangan dari metode AHP (Analytical Hierarchy Process) yang menguraikan masalah multi faktor atau multi kriteria yang kompleks menjadi suatu hirarki, sehingga permasalahan akan tampak lebih terstruktur dan sistematis. Namun hasil keputusan yang didapatkan dengan menggunakan Fuzzy AHP lebih baik karena mampu meminimalisir deskripsi keputusan yang sama-samar yang di hasilkan dari metode AHP.

Langkah penyelesaian Fuzzy AHP adalah sebagai berikut [16];

a. Membuat struktur hierarki masalah yang akan diselesaikan dan menentukan perbandingan matriks berpasangan antar kriteria dengan skala TFN (Tringular Fuzzy Number).

b. Menentukan nilai sintesis fuzzy ( $\mathrm{Si}$ ) prioritas dengan rumus:

$$
S i=\sum_{j=1}^{m} M_{i}^{j} \mathrm{x} \frac{1}{\sum_{i=1}^{n} \sum_{j=1}^{\mathrm{m}} \mathrm{M}_{i}^{j}}
$$

Menentukan nilai vektor (V) dan nilai Ordinat Defuzzifikasi (d').

Untuk $k=1,2, \ldots \mathrm{n} ; \mathrm{k} \neq i$, maka diperoleh nilai bobot vektor:

$$
W^{\prime}=\left(d^{\prime}\left(A_{1}\right), d^{\prime}\left(A_{2}\right), \ldots, d^{\prime}\left(A_{n}\right)\right)^{T}
$$

Misalkan $A_{1}=\left(l_{1}, \mathrm{u}_{1}\right) ; A_{2}=\left(l_{2}, \mathrm{u}_{2}\right)$. Maka matriks penilaian gabungan dirumuskan sebagai berikut:

$$
A_{g}(l, u)=\sqrt[2]{\left(l_{1} * l_{2}\right),\left(u_{1} * u_{2}\right)}
$$

c. Normalisasi nilai bobot vektor fuzzy $(W)$

Nilai bobot vektor yang ternormalisasi adalah seperti rumus berikut:

$$
\mathrm{W}=\left(\mathrm{d}\left(\mathrm{A}_{1}\right), \mathrm{d}\left(\mathrm{A}_{2}\right), \ldots, \mathrm{d}\left(\mathrm{A}_{\mathrm{n}}\right)\right)^{\mathrm{T}}
$$

Dimana $\mathrm{W}$ adalah bilangan non fuzzy.

Perumusan normalisasinya adalah:

$$
d\left(A_{n}\right)=\frac{d^{\prime}}{\sum_{i=1}^{n} d^{\prime}\left(A_{n}\right)}
$$

\section{TOPSIS (Technique for Order Preference by Similarity to Ideal Solution).}

Metode TOPSIS diperkenalkan pertama kali oleh Yoon dan Hwang tahun 1981 [17] merupakan metode pengambilan keputusan multikriteria, metode ini bertujuan untuk menentukan solusi ideal positif dan solusi ideal negatif dimana alternatif yang terbaik di pilih dari yang paling dekat dengan solusi ideal positif dan yang paling jauh dari solusi ideal negatif.

Langkah penyelesaian permasalahan dengan menggunakan metode TOPSIS adalah sebagai berikut [18]:

1. Membangun normalisasi decision matrix. Elemen $r_{i j}$ hasil dari normalisasi dengan metode Euclidean length of a factor adalah:

$$
\begin{aligned}
r_{i j} & =\frac{x_{i j}}{\sqrt{\sum_{i=1}^{m} x_{i j}^{2}}} \\
x_{i j} & =\text { nilai asli matriks keputusan }
\end{aligned}
$$


$r_{i j}=$ nilai ternormalisasi matriks keputusan

2. Membangun weighted normalized decision matrix dengan bobot

$\left(w=w_{1}, w_{2}, w_{3} \ldots . . w_{n}\right)$, maka normalisasi bobot matriks $\mathrm{V}$ adalah:

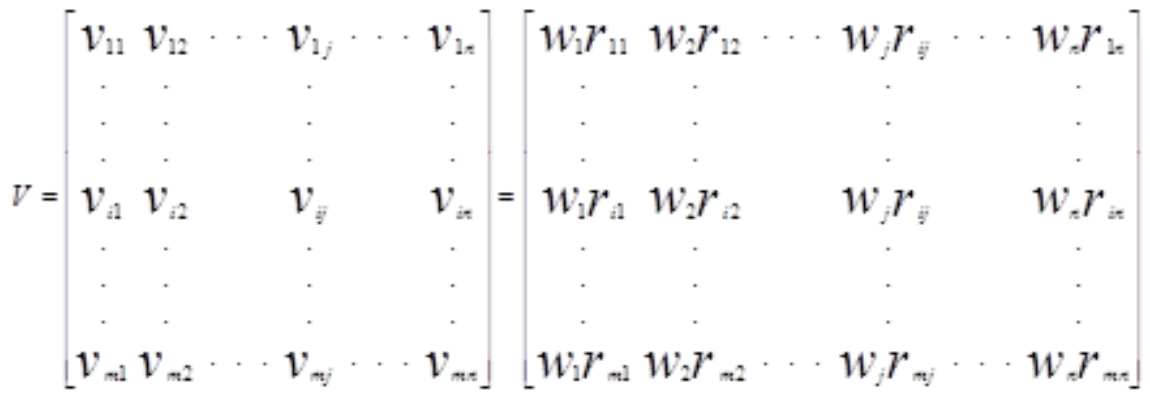

3. Menentukan solusi ideal dan solusi ideal negatif, dimana $A^{+}$adalah solusi ideal sedangkan $A^{-}$dinotasikan sebagai solusi ideal negatif.

$$
\begin{aligned}
A^{+} & \left.=\left\{\left(\max v_{i j} \mid j \in J\right), \min v_{i j} \mid j \in J\right) \mid i=1,2, \ldots m\right\} \\
& =\left\{v_{1}^{+}, v_{2}^{+}, \ldots v_{j}^{+}, \ldots v_{n}^{+}\right\} \\
A^{-} & \left.=\left\{\left(\max v_{i j} \mid j \in J\right), \min v_{i j} \mid j \in J\right) \mid i=1,2, \ldots m\right\} \\
& =\left\{v_{1}^{-}, v_{2}^{-}, \ldots v_{j}^{-}, \ldots v_{n}^{-}\right\}
\end{aligned}
$$

Dimana $J=\{j=1,2, \ldots, n \mid j$ associated with benefit criteri $\}$

$J=\{j=1,2, \ldots, n \mid j$ associated with cost criteri $\}$

4. Mengukur separation measure. Ideal separation dan negative ideal separation

$$
\begin{aligned}
& \text { Ideal separation } S_{i}^{+}=\sqrt{\sum_{j=1}^{n}\left(v_{i j}-v_{j}^{+}\right)^{2}} \quad i=1,2,3, \ldots, m \\
& \text { Negatif Ideal separation } S_{i}^{-}=\sqrt{\sum_{j=1}^{n}\left(v_{i j}-v_{j}^{-}\right)^{2}} \quad i=1,2,3 \ldots, m
\end{aligned}
$$

5. Menghitung kedekatan relatif terhadap solusi ideal

$$
\begin{aligned}
& C_{1}^{*}=\frac{s_{i}^{-}}{S_{i}^{+}+S_{i}^{-}}, 0<c_{1}^{+}<1 i=1,2,3, \ldots m \\
& C_{i}^{*}=1 \text { jika } A_{1}=A^{+} \\
& \mathrm{C}_{\mathrm{i}}^{*}=0 \text { jika } \mathrm{A}_{1}=\mathrm{A}^{-}
\end{aligned}
$$

6. Menyusun peringkat berdasarkan nilai $C_{i}^{*}$

\section{HASIL DAN PEMBAHASAN}

\section{Identifikasi Kriteria Pemilihan Supplier}

Kriteria pemilihan supplier didapatkan dari hasil review literatur, kemudian diverifikasi kepada experts yang dianggap kompeten dalam bidang industri fashion. Expert yang diwawancarai oleh peneliti sebanyak empat orang yang telah memenuhi syarat, kemudian dilanjutkan dengan pemberian kuisioner. Kriteria yang digunakan dalam penelitian ini yaitu: 1) Delivery (D), indikatornya adalah lokasi geografis, ketentuan pengiriman, total order lead time; untuk flexibility indikatornya adalah kapasitas, inventory, availability, information sharing, negotiability, dan customization;2) cost $(C)$, indikatornya adalah supplier selling cost, internal cost, ordering dan invoice; 3) quality $(Q)$ indikatornya adalah continues improvement program, customer service, certification, dan on time shipment; reliability, feeling of trust, country's political situation, currency exchange, dan situation warranty police; 4) product variety (PV) indikatornya adalah size, 
shape, dan structure; dan 5) style (S) indikatornya adalah color dan appearance. Sedangkan

\section{Penilaian Kriteria}

Penilaian bobot kepentingan masing-masing kriteria dilakukan oleh empat orang expert untuk menjadi responden dalam penelitian ini. Hasil yang diperoleh melalui pengisian kuisioner adalah perbandingan antar kriteria. Dalam penilaian kepentingan relatif dua elemen, berlaku aksioma reciprocal dimana jika elemen pada kolom pertama diberi nilai 3 kali lebih penting dibandingkan dengan elemen pada kolom kedua, maka elemen pada kolom kedua harus sama dengan 1/3 kali lebih penting dibanding elemen pada kolom pertama. Matriks perbandingan berpasangan antar kriteria ini diperoleh dari hasil kuisioner yang telah diisi oleh expert dapat dilihat pada tabel di bawah ini.

Tabel 1. Hasil Penilaian Kriteria

\begin{tabular}{cccccccccccccccc}
\hline & & PV & & S & Q & Q & & C & & D \\
\hline PV & 1 & 1 & 2 & 8 & 9 & 10 & 6 & 7 & 8 & 4 & 5 & 6 & 1 & 1 & 2 \\
S & $1 / 10$ & $1 / 9$ & $1 / 8$ & 1 & 1 & 2 & 6 & 7 & 8 & 2 & 3 & 4 & 1 & 1 & 2 \\
Q & $1 / 8$ & $1 / 7$ & $1 / 6$ & $1 / 8$ & $1 / 6$ & $1 / 7$ & 1 & 1 & 2 & 4 & 5 & 6 & 4 & 5 & 6 \\
C & $1 / 6$ & $1 / 5$ & $1 / 4$ & $1 / 4$ & $1 / 3$ & $1 / 2$ & $1 / 6$ & $1 / 5$ & $1 / 4$ & 1 & 1 & 2 & 2 & 3 & 4 \\
D & $1 / 2$ & 1 & 1 & $1 / 2$ & 1 & 1 & $1 / 6$ & $1 / 5$ & $1 / 4$ & $1 / 4$ & $1 / 3$ & $1 / 2$ & 1 & 1 & 2 \\
\hline
\end{tabular}

\section{Penilaian Sub Kriteria}

Untuk sub-kriteria, dilakukan berdasarkan masing-masing kriteria. Penilaian bobot kepentingan masing-masing sub-kriteria dilakukan oleh empat orang pakar yang dipilih untuk menjadi responden dalam penelitian ini.

Tabel 2. Hasil Penilaian Sub Kriteria Product Variety

\begin{tabular}{lccccccccc}
\hline & \multicolumn{3}{c}{ Size } & \multicolumn{3}{c}{ Shape } & \multicolumn{3}{c}{ Structure } \\
\hline Size & 1 & 1 & 2 & $1 / 8$ & $1 / 7$ & $1 / 6$ & $1 / 8$ & $1 / 7$ & $1 / 6$ \\
Shape & 6 & 7 & 8 & 1 & 1 & 2 & 6 & 7 & 8 \\
Structure & 6 & 7 & 8 & $1 / 8$ & $1 / 6$ & $1 / 7$ & 1 & 1 & 2 \\
\hline
\end{tabular}

\section{Pemilihan Alternative}

Untuk alternative dilakukan berdasarkan masing-masing sub kriteria. Penilaian bobot kepentingan alternative dilakukan oleh empat orang pakar yang dipilih untuk menjadi responden dalam penenlitian ini.

Tabel 3. Hasil Penilaian Alternative Size

\begin{tabular}{cccccccccccccccc}
\hline & HP & \multicolumn{1}{c}{ PRL } & \multicolumn{3}{c}{ TE } & \multicolumn{3}{c}{ C } & \multicolumn{3}{c}{ BK } \\
\hline HP & 1 & 1 & 2 & $1 / 6$ & $1 / 5$ & $1 / 4$ & $1 / 8$ & $1 / 7$ & $1 / 6$ & $1 / 2$ & 1 & 1 & $1 / 6$ & $1 / 5$ & $1 / 4$ \\
PRL & 4 & 5 & 6 & 1 & 1 & 2 & $1 / 6$ & $1 / 5$ & $1 / 4$ & 4 & 5 & 6 & $1 / 6$ & $1 / 5$ & $1 / 4$ \\
TE & 6 & 7 & 8 & 4 & 5 & 6 & 1 & 1 & 2 & 6 & 7 & 8 & $1 / 4$ & $1 / 3$ & $1 / 2$ \\
C & 1 & 1 & 2 & $1 / 6$ & $1 / 5$ & $1 / 4$ & $1 / 8$ & $1 / 7$ & $1 / 6$ & 1 & 1 & 2 & $1 / 6$ & $1 / 5$ & $1 / 4$ \\
BK & 4 & 5 & 6 & 4 & 5 & 6 & 2 & 3 & 4 & 4 & 5 & 6 & 1 & 1 & 2 \\
\hline
\end{tabular}

\section{Hasil Pengolahan Fuzzy Analytical Hierarchy Process}

\section{Konversi Skala Triangular Fuzzy Number}

Skala bilangan yang telah dibuat pada matriks berpasangan, kemudian dikonversi menjadi skala TFN (Triangular Fuzzy Number). Angka fuzzy biasanya ditunjukkan dalam bentuk tiga angka yaitu $(l, m, u)$. Parameter tersebut melambangkan kumungkinan nilai 
terkecil, nilai yang menjanjikan, dan nilai terbesar yang merepresentasikan masalah fuzzy. Berikut rumus yang digunakan dalam mengkonversi hasil kuisioner.

$$
\begin{aligned}
& \text { Batas Bawah }(\mathrm{BB})=((\mathrm{m} \mathrm{l}) * 0,5)+1 \\
& \text { Batas Atas }(\mathrm{BA})=((\mathrm{u}-\mathrm{m}) * 0,5)+\mathrm{u}
\end{aligned}
$$

Tabel berikut merupakan penilaian kriteria dan sub kriteria yang telah diisi oleh pakar dan konversi angka-angka fuzzy di dalamnya.

Tabel 4. Hasil Penilaian Kriteria

\begin{tabular}{ccccccccccc}
\hline & \multicolumn{1}{c}{ PV } & \multicolumn{2}{c}{ S } & \multicolumn{2}{c}{$\mathbf{Q}$} & \multicolumn{2}{c}{$\mathbf{C}$} & \multicolumn{2}{c}{$\mathbf{D}$} \\
\hline PV & 1,00 & 1,50 & 8,50 & 9,50 & 6,50 & 7,50 & 4,50 & 5,50 & 1,00 & 1,50 \\
S & 0,11 & 0,12 & 1,00 & 1,50 & 6,50 & 7,50 & 2,50 & 3,50 & 2,00 & 2,50 \\
Q & 0,13 & 0,15 & 0,15 & 0,15 & 1,00 & 1,50 & 4,50 & 5,50 & 4,50 & 5,50 \\
C & 0,18 & 0,23 & 0,29 & 0,42 & 0,18 & 0,23 & 1,00 & 1,50 & 2,50 & 3,50 \\
D & 0,75 & 1,00 & 0,75 & 1,00 & 0,18 & 0,23 & 0,29 & 0,42 & 1,00 & 1,50 \\
\hline
\end{tabular}

Tabel 5. Hasil Penilaian SubKriteria Product Variety

\begin{tabular}{lllllll}
\hline & \multicolumn{2}{c}{ Size } & \multicolumn{2}{c}{ Shape } & \multicolumn{2}{c}{ Structure } \\
\hline Size & 1,00 & 1,50 & 0,13 & 0,15 & 0,13 & 0,15 \\
Shape & 6,50 & 7,50 & 1,00 & 1,50 & 6,50 & 7,50 \\
Structure & 6,50 & 7,50 & 0,15 & 0,15 & 1,00 & 1,50 \\
\hline
\end{tabular}

Tabel 6. Hasil Penilaian Alternative Size

\begin{tabular}{ccccccccccc}
\hline & \multicolumn{2}{c}{ HP } & \multicolumn{2}{c}{ PRL } & \multicolumn{2}{c}{ TE } & \multicolumn{2}{c}{ C } & \multicolumn{2}{c}{ BK } \\
\hline HP & 1,00 & 1,50 & 0,18 & 0,23 & 0,13 & 0,15 & 0,75 & 1,00 & 0,18 & 0,23 \\
PRL & 4,50 & 5,50 & 1,00 & 1,50 & 0,18 & 0,23 & 4,50 & 5,50 & 0,18 & 0,23 \\
TE & 6,50 & 7,50 & 4,50 & 5,50 & 1,00 & 1,50 & 6,50 & 7,50 & 0,29 & 0,42 \\
C & 1,00 & 1,50 & 0,18 & 0,23 & 0,13 & 0,15 & 1,00 & 1,50 & 0,18 & 0,23 \\
BK & 4,50 & 5,50 & 4,50 & 5,50 & 2,50 & 3,50 & 4,50 & 5,50 & 1,00 & 1,50 \\
\hline
\end{tabular}

\section{Defuzzifikasi Matriks Penilaian}

Sebelum melakukan defuzzifikasi, hasil penilaian responden satu dan dua akan digabungkan menjadi satu matriks penilaian. Berikut merupakan matriks penilaian gabungan dalam pembobotan kriteria dan sub kriteria.

Metode defuzzifikasi yang digunakan adalah metode untuk mengkonversi nilai fuzzy ke dalam bentuk nilai crisp yang diperkenalkan oleh Opricovic dan Zheng yaitu metode CFCS (Converting Fuzzy Into Crisp scores). Perhitungan nilai crisp untuk tingkat keyakinan nilai fuzzy $\alpha=0,5$ mengikuti persamaan berikut.

Nilai Crisp $=0,5 * 1+(1-0,5) * u$

Tabel 7. Matriks Crisp Gabungan Penilaian Kriteria

\begin{tabular}{cccccc}
\hline & PV & S & Q & C & D \\
\hline PV & 1,00 & 1,00 & 0,38 & 1,45 & 0,63 \\
S & 1,44 & 1,00 & 0,45 & 2,15 & 0,37 \\
$\mathbf{Q}$ & 2,65 & 2,26 & 1,00 & 2,44 & 0,60 \\
C & 0,71 & 0,48 & 0,42 & 1,00 & 0,46 \\
D & 1,66 & 3,22 & 1,74 & 2,27 & 1,00 \\
& 7,47 & 7,67 & 3,99 & 9,31 & 3,05 \\
\hline
\end{tabular}




\section{Hasil Uji Konsistensi}

Setelah melakukan defuzzifikasi, maka langkah selanjutnya adalah melakukan uji konsistensi untuk mengetahui apakah matriks berpasangan tersebut konsisten atau tidak. Uji konsistensi dilakukan dengan menghitung nilai consistency index (CI.) dan consistency rate (CR.) untuk nilai tengah pada matriks fuzzy. Menurut Saaty, batas nilai CR. adalah 0,1 . Berikut adalah hasil perhitungan $\mathrm{CR}$. untuk matriks perbandingan kriteria dan sub kriteria.

Tabel 8. Hasil Perhitungan Eigenvektor Kriteria

\begin{tabular}{cccccccc}
\hline & PV & S & Q & C & D & Bobot & Ranking \\
\hline PV & 0,13 & 0,09 & 0,10 & 0,16 & 0,21 & 0,14 & $\mathbf{4}$ \\
S & 0,19 & 0,13 & 0,11 & 0,23 & 0,12 & 0,16 & $\mathbf{3}$ \\
$\mathbf{Q}$ & 0,36 & 0,29 & 0,25 & 0,26 & 0,20 & 0,27 & $\mathbf{2}$ \\
C & 0,10 & 0,06 & 0,10 & 0,11 & 0,15 & 0,10 & $\mathbf{5}$ \\
$\mathbf{D}$ & 0,22 & 0,42 & 0,44 & 0,24 & 0,33 & 0,33 & $\mathbf{1}$ \\
& 1,00 & 1,00 & 1,00 & 1,00 & 1,00 & 1,00 & \\
\hline
\end{tabular}

Setelah dilakukan perhitungan eigenvektor, maka langkah selanjutnya adalah melakukan perhitungan $\Lambda$ maks, CI. dan CR. untuk menguji konsistensi matriks berpasangan yang ada. Berikut rumus untuk menghitung nilai $\mathrm{CR}$.

$$
\mathrm{CR} .=\frac{C . I}{R . I}
$$

Setelah dilakukan perhitungan uji konsistensi tersebut, maka diperoleh nilai CR untuk kriteria dan sub kriteria adalah sebagai berikut.

Tabel 9. Hasil Perhitungan CI dan CR

\begin{tabular}{ccccccc}
\hline & Kriteria & Sub Kriteria 1 & Sub Kriteria 2 & Sub Kriteria 3 & Sub Kriteria 4 & Sub Kriteria 5 \\
\hline CI & 0,07 & 0,10 & 0,05 & 0.03 & 0,08 & 0,11 \\
CR & 0,06 & 0,09 & 0,05 & 0,03 & 0,07 & 0,10 \\
\hline
\end{tabular}

Dari hasil perhitungan nilai CR. dan CI., sehingga dapat disimpulkan bahwa matriks berpasangan tersebut konsisten, dan hasil pembobotan kriteria yang ada dalam matriks tersebut dapat dipakai untuk pengolahan data selanjutnya.

Tabel 10. Bobot Akhir Fuzzy AHP

\begin{tabular}{ccccccccccccccccc}
\hline & Si & Sh & Struc & Co & APP & BP & OTS & CS & Certi & SSP & O\&I & IC & GL & TOLT & FT & \multirow{2}{*}{ Bobot } \\
& $\mathbf{0 , 1 5}$ & $\mathbf{0 , 1 4}$ & $\mathbf{0 , 0 5}$ & $\mathbf{0 , 1 6}$ & $\mathbf{0 , 0 7}$ & $\mathbf{0 , 0 7}$ & $\mathbf{0 , 0 4}$ & $\mathbf{0 , 0 7}$ & $\mathbf{0 , 0 2}$ & $\mathbf{0 , 0 5}$ & $\mathbf{0 , 1 0}$ & $\mathbf{0 , 0 2}$ & $\mathbf{0 , 0 3}$ & $\mathbf{0 , 0 6}$ & $\mathbf{0 , 0 2}$ & \\
\hline HP & 0,30 & 0,33 & 0,27 & 0,17 & 0,08 & 0,16 & 0,17 & 0,10 & 0,16 & 0,10 & 0,09 & 0,18 & 0,08 & 0,15 & 0,16 & 0,20 \\
PRL & 0,30 & 0,31 & 0,42 & 0,47 & 0,17 & $0 ., 7$ & 0,40 & 0,25 & 0.49 & $0 ., 17$ & 0,14 & 0,40 & 0,13 & 0,42 & 0,29 & 0,33 \\
TE & 0,11 & 0,11 & 0,10 & 0,15 & 0,10 & 0,16 & 0,13 & 0,10 & 0,16 & 0,09 & 0,08 & 0,13 & 0,08 & 0,14 & 0,11 & 0,12 \\
C & 0,18 & 0,16 & 0,13 & 0,12 & 0,59 & 0,13 & 0,22 & 0,33 & 0,12 & 0,05 & 0,27 & 0,22 & 0,25 & 0,23 & 0,38 & 0,22 \\
BK & 0,11 & 0,09 & 0,08 & 0,09 & 0,05 & 0,07 & 0,07 & 0,23 & 0,07 & 0,05 & 0,42 & 0,07 & 0,46 & 0,07 & 0,06 & 0,14 \\
\hline
\end{tabular}

Keterangan:

\begin{tabular}{|c|c|c|c|}
\hline $\mathrm{Si}$ & : Size & Certi & : Certification \\
\hline$S h$ & : Shape & SSP & : Supplier Selling Price \\
\hline Struc & : Structure & O\&I & :Ordering \& Invoice \\
\hline Co & : Colour & $\mathrm{IC}$ & : Internal Cost \\
\hline App & : Appearance & GL & : Geographic Location \\
\hline $\mathrm{BP}$ & : Brand Product & TOLT & : Total Order Lead Time \\
\hline OTS & : On Time Shipping & FT & : Freight Terms \\
\hline CS & : Customer Service & & \\
\hline
\end{tabular}

\section{Hasil Perhitungan TOPSIS}

\section{Perhitungan Ideal Positif dan Ideal Negatif}

Dari perhitungan nilai Fuzzy synthetic extend maka dapat dilanjutkan untuk menghitung nilai ideal positif dan ideal negatif. Dimana nilai ini digunakan untuk 
mendapatkan bobot akhir dari perhitungan TOPSIS. Perhitungan nilai ideal postif dan ideal negatif yaitu dengan cara nilai fuzzy synthetic extend setiap alternatif digabung terlebih dahulu. Penggabungan nilai fuzzy synthetic extend tiap alternatif dapat dilihat pada Tabel berikut.

Tabel 11. Penggabungan Nilai Fuzzy Synthetic Extend Tiap Alternatif

\begin{tabular}{cccccccccccccccc}
\hline & Size & Shape & Structure & Colour & APP & BP & OTS & CS & Certi & SSP & O\&I & IC & GL & TOLT & FT \\
\hline HP & 0,30 & 0,33 & 0,27 & 0,17 & 0,08 & 0,16 & 0,17 & 0,10 & 0,16 & 0,10 & 0,09 & 0,18 & 0,08 & 0,15 & 0,16 \\
PRL & 0,30 & 0,31 & 0,42 & 0,47 & 0,17 & 0,47 & 0,40 & 0,25 & 0,49 & 0,17 & 0,14 & 0,40 & 0,13 & 0,42 & 0,29 \\
TE & 0,11 & 0,11 & 0,10 & 0,15 & 0,10 & 0,16 & 0,13 & 0,10 & 0,16 & 0,09 & 0,08 & 0,13 & 0,08 & 0,14 & 0,11 \\
C & 0,18 & 0,16 & 0,13 & 0,12 & 0,59 & 0,13 & 0,22 & 0,33 & 0,12 & 0,05 & 0,27 & 0,22 & 0,25 & 0,23 & 0,38 \\
BK & 0,11 & 0,09 & 0,08 & 0,09 & 0,05 & 0,07 & 0,07 & 0,23 & 0,07 & 0,05 & 0,42 & 0,07 & 0,46 & 0,07 & 0,06 \\
\hline
\end{tabular}

Tabel 12. Hasil Perhitungan Jarak Antar Nilai

\begin{tabular}{lcc}
\hline & Di* $^{*}$ & $\boldsymbol{D}_{\boldsymbol{i}}^{-}$ \\
\hline $\mathrm{HP}$ & 1,00 & 0,44 \\
$\mathrm{PRL}$ & 0,62 & 1,06 \\
$\mathrm{TE}$ & 1,10 & 0,19 \\
$\mathrm{C}$ & 0,80 & 0,78 \\
$\mathrm{BK}$ & 1,11 & 0,53 \\
\hline
\end{tabular}

Tabel 13. Hasil Perhitungan Nilai Preferensi

\begin{tabular}{lccc}
\hline & Di* $^{*}$ & $\boldsymbol{D}_{\boldsymbol{i}}^{-}$ & $\mathrm{Ci}^{*}$ \\
\hline HP & 1,00 & 0,44 & 0,30 \\
PRL & 0,62 & 1,06 & 0,63 \\
TE & 1,10 & 0,19 & 0,15 \\
C & 0,80 & 0,78 & 0,49 \\
BK & 1,11 & 0,53 & 0,32 \\
\hline
\end{tabular}

Berdasarkan perhitungan bobot akhir dengan TOPSIS maka diperoleh merk PRL sebagai peringkat 1 dengan bobot 0.63 .

\section{KESIMPULAN}

Berdasarkan hasil pengolahan data dan analisis menggunakan metode fuzzy AHP dapat diambil kesimpulan bahwa hasil perhitungan fuzzy AHP menunjukkan bahwa kriteria yang paling penting dalam pemilihan supplier yaitu pengiriman dengan bobot 0,33 . Hasil ini dapat digunakan sebagai dasar dalam pengambilan keputusan dalam menjalin kerja sama dengan supplier. Selain itu dari hasil pengolahan data sub kriteria pertama di dapatkan bahwa structure lebih penting dengan bobot kepentingan sebesar 0.51 sedangkan alternative yang terpilih dari setiap sub kriteria yang ada yaitu size merek HP, shape merek BK dan structure merek HP. Dengan melihat hasil yang diperoleh dengan menggunakan metode fuzzy AHP alternative terbaik adalah PRL, diikuti C, HP, BK dan terakhir TE dengan bobot masing-masing 0,33;0,22;0,20;0,14dan 0,12 sedangkan metode TOPSIS alternative terbaik adalah merek PRL dengan bobot 0,63 kedua merk $\mathrm{C}$ dengan bobot 0,49 , ketiga merek BK dengan bobot 0,32 selajutnya HP dan TE dengan bobot berturut-turut 0,3 dan 0,15

\section{DAFTAR PUSTAKA}

[1]. Beil, Damian R. (2009). "Supplier Selection." Wiley of Encyclopedia of Operations Research and Management Science.

[2]. Saaty, TL.; Vargas, L.G. (1993). Models, Methods, Concept \& Aplications of The Analytic Hierarchy Process. Internationel Series in Operations Research \& Management Science. Second Edition. New York: Springer. 
[3]. Ngatawi, dan Setyaningsih, I. (2011), Analisis Pemilihan Supplier menggunakan Analytical Hierarchy Process. Jurnal Ilmiah Teknik Industri. Vol.10, No.1 Hal 7-13

[4]. Balli, Serkan and Korukoğlu, Serdar. (2009) "Operating System Selection Using Fuzzy AHP and TOPSIS Methods". Mathematical and Computational Applications, Vol. 14, No. 2, pp. 119130.

[5]. Dagdeviren, M, dan Yavuz, S, Kilinc, N (2009), "Weapon selection using the AHP and TOPSIS methods under fuzzy environment", Expert System with Applications, 36, Hal. 8143-8151.

[6]. Onut, S dan Soner, S (2008),'Transhippment site selections using the AHP and TOPSIS approaches under fuzzy environment", Waste Management, 28, Hal 15521559.

[7]. Muhardono, A dan Isnanto, R. R. (2014).” Penerapan Metode AHP dan Fuzzy Topsis Untuk Sistem Pendukung Keputusan Promosi Jabatan". Jurnal Sistem Informasi Bisnis. Vol.4, No.2, Hal 108 - 115.

[8]. Sabiq, A. (2013). "Metode Fuzzy AHP dan Fuzzy TOPSIS Untuk Pemilihan Distro Linux". Orbith, Vol. 9, No. 2, Hal 78 - 83.

[9]. Pramudhita, A.N., Suyono.H, Yudaningtyas E., (2015). "Penggunaan Algoritma Multi Criteria Decision Making dengan Metode Topsis dalam Penempatan Karyawan". Jurnal EECCIS Vol. 9, No. 1, Hal 91 - 94.

[10]. Simpson, P., Siguaw, J. and White, S. (2002). "Measuring The Performance of Suppliers: An Analysis of Evaluation Process." The Journal of Supply Chain Management, Vol. 38 No. 1, pp. 29-41.

[11]. Chaudhry, Hassan. and Hodge, George (2012). "Postponement and Supply Chain Structure: Cases from The Textile and Apparel Industry", Journal of Fashion Marketing and Management: An International Journal, Vol. 16 Iss 1 pp. 64 - 80

[12]. Bruce, Margaret. and Daly, Lucy. (2006). 2006),"Buyer Behaviour for Fast Fashion", Journal of Fashion Marketing and Management: An International Journal, Vol. 10 Iss 3 pp. $329-344$.

[13]. Kim, Bowon. (2013). "Competitive Priorities and Supply Chain Strategy in The Fashion Industry", Qualitative Market Research: An International Journal, Vol. 16 Iss 2 pp. $214-242$.

[14]. Kubendran, S. and Vasumathi, Dr. A. M. (2015).”Optimization of Supplier Selection Using Fuzzy Analytical Hierarchy Process - State of Art Study." Internation Journal of Innovative Research in Science, Engineering, and Technology, Vol. 4, Iss 5.

[15]. Teng, S. Gary. and Jaramilo, Hector. (2005). "A Model for Evaluation and Selection of Suppliers in Global Textile and Apparel Supply Chains", International Journal of Physical Distribution \& Logistics Management, Vol. 35 Iss 7 pp. 503 - 523

[16]. Chang, D. Y. 1996. Application of the Extend Analysis Method on Fuzzy AHP. European Journal of Operational Research 95, 649-655.

[17]. Hwang, C.L. dan Yoon, K., 1981, Multiple Attribute Decision Making: Methods and Applications, Springer-Verlag, New York.

[18]. Achebo,J., Omoregie,M. (2015). "Application of Multi-Criteria Decision Making Optimization Tool for Determining Mild Steel Weld Properties and Process Parameters Using the TOPSIS". International Journal of Materials Science and Applications. Volume 4, Issue 3, Pages: 149-158. 